\title{
BIRC2 wt Allele
}

National Cancer Institute

\section{Source}

National Cancer Institute. BIRC2 wt Allele. NCI Thesaurus. Code C49354.

Human BIRC2 wild-type allele is located in the vicinity of $11 \mathrm{q} 22$ and is approximately 30 $\mathrm{kb}$ in length. This allele, which encodes baculoviral IAP repeat-containing protein 2, plays a role in the inhibition of apoptosis through caspase inactivation. 